\title{
Thirty Years of Reform and Opening Up: Teaching International Relations in China
}

Patrice C. McMahon, University of Nebraska-Lincoln,

with Yue Zou, University of Nebraska-Lincoln

ABSTRACT In 1978, Deng Xiaoping declared that China's future depended on gaige kaifang (reform and opening up to the West). By any standard, China has reformed its economic system and prospered handsomely by integrating into the world economy. With less fanfare, China has taken steps to restructure its political system and committed substantial resources to harmonizing relations with its neighbors. Given these changes, China's insular tradition, and Communist government, this article considers how the country's reemergence has impacted the teaching of international relations (IR) at Chinese universities. Using primary and secondary sources, including university Web sites written in Chinese and English, and about a dozen semi-structured interviews conducted in Beijing and Xi' an, this study concludes that although China has become actively engaged in IR and the internationalization of universities is evident, the government has yet to endorse fully the importance of IR as a discipline, and universities have not systematically adopted the theoretical toolbox developed outside of China to describe, explain, and predict behavior in IR.

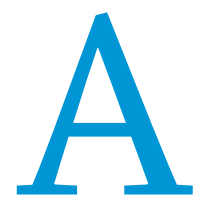

$S$ the host of the 2008 Olympics, the 2010 World Expo, and, more important, the focus of Nickelodeon's popular Ni-Hao, Kai-lan series, China has clearly become the international rock star of our era. The once-isolated People's Republic of China (PRC) is a member of over 260 international conventions and most major international organizations (Yaqing 2007). It has transformed its economy and lifted 400 million people out of poverty, and by the middle of this century, many economists predict that China's GDP will surpass that of the United States as the world's

Patrice C. McMahon is an associate professor at the University of Nebraska-Lincoln. Her research focuses on ethnic conflict and cooperation, post-conflict reconstruction, and global governance. She is the author of Taming Ethnic Hatreds: Ethnic Cooperation and Transnational Networks in Eastern Europe (Syracuse University Press, 2007). Her work has appeared in Foreign Affairs, Political Science Quarterly, Democratization, and Ethnopolitics. She can be reached at pmcmahonz@unl.edu. Yue Zou received her bachelor's and master's degrees in political science from Sun Yat-Sen University in China. She is pursuing her Ph.D. in political science from the University of Nebraska-Lincoln. Her research interests are ethnic conflict, political behavior, and ChineseAmerican relations. She can be reached at zouyueo5@gmail.com. largest. With less fanfare, China has taken measured steps to refine its political system, making it a model of stability and growth for developing countries. The nation has also committed substantial resources to international relations (IR), mending conflicts with its enemies and harmonizing relations with its neighbors. Simply put, China is now a key stakeholder in the international system.

Given China's profound domestic and international changes, insular tradition, and Communist government, I wondered how gaige kaifang, its program of reform and opening up to the West that was launched in 1978, has impacted the openness of Chinese universities. As a professor of IR but not a China expert, I specifically wanted to know how China's new international posture had affected the teaching of IR. These were a few of the questions that I had when I first visited Xi' an, a city of 8 million in central China in 2007 , to discuss the possibility of teaching a graduate course in the School of Public Policy and Administration at Xi'an Jiaotong University (XJTU) in the spring of 2008. In 2009, I again returned to XJTU to teach a class called "Global Challenges." On any given day, 40 Chinese students would fill the classroom to discuss (in almost perfect English) global issues. My three years of travel and 
teaching in China presented the question that I explore here: how has China's embrace of the West affected the internationalization of its universities, and specifically the teaching of IR? ${ }^{1}$

I argue that "reform and opening up to the West" has indeed internationalized Chinese universities and "the integration of an international or intercultural dimension into curricula, research, and service" is commonplace throughout the country (Knight 2004, 7). China's embrace of the West has also influenced the discipline and teaching of IR, but these changes are uneven and depend on individual universities and their priorities. The field of IR started in China in the 196os, when political science was officially banned, and experienced a renaissance in the 1990s. ${ }^{2}$ IR classes are now taught at top social science universities, and a small but dynamic community of scholars exists that is committed to social science inquiry (see Zhang 2002). The formal study of IR, however, is still clustered regionally within China and is constrained by the country's centralized and specialized approach to education, which contin- views in 2008 with Chinese and foreign professors working in this area and corresponded by e-mail with academics in China and the United States throughout 2009.

\section{INTERNATIONALIZING CHINESE UNIVERSITIES}

There is an extensive literature on the internationalization of higher education in China that explains why and how universities have integrated an international or intercultural dimension into teaching, research, and service (Li 2007; Su and Liang 2007; Xu and Xie 2003; Wang 1999). Scholarship focuses on four main areas: the theory of internationalization in higher education, the current status of internationalization, strategies adopted by universities to internationalize their campuses, and characteristics of and problems with internationalization. Only a few scholars link the internationalization of Chinese universities to what Chinese students are learning about the world or the need for more classes on other countries, cultures, or the international system (Yang 2005, 99). One scholar

\section{The 1978 reforms have had an obvious impact on Chinese universities, their openness to ideas from abroad, and the ability of students to learn more about the world, if only informally. The large numbers of Chinese people going abroad and foreigners coming to China continue to provide students with significant international exposure. Chinese students have been studying abroad since the 1980s, but the number is rising rapidly. Between 1978 and 2006, more than one million Chinese studied abroad; in 2008 alone, almost 180,000 students left to study overseas.}

ues to be dominated by technical universities and teacher-training colleges. Six institutions provide the foundation for IR studies in China, and the Chinese government continues to look for diplomats and foreign policy experts in these places (Jisi 2002). This focus on a small pool of schools is why even prestigious universities (like XJTU) do not offer IR classes. ${ }^{3}$ Put differently, although China has become actively engaged in IR and the internationalization of universities is evident, the government has yet to endorse fully the importance of IR as a discipline, and universities have not systematically adopted the theoretical toolbox developed outside of China to describe, explain, and predict behavior in IR.

To help me assess the impact of gaige kaifang on what and how IR is taught in China, I enlisted the assistance of Chinese graduate students. Searches conducted in Chinese provided significant information on the internationalization of higher education in China that started to occur in the 1980s; several articles and books focused on the state of IR research and a few discussed the teaching of dangdai shijie jingji yu zhengzhi (contemporary world economy and politics), which is recommended by the Communist Party and the Ministry of Education (Junling 2003; Li 2003; Du and Wu 1994). Infused with Marxist ideology, these articles explain how political theory should be taught in Communist China. Searches conducted in English bore similar results, although a few articles had also been published about the challenges of teaching political science in China (Petracca 1990; Bell 2006). This study, which relies on primary and secondary sources including university Web sites, fills this gap and links China's 1978 reforms to what and how IR is approached in China in 2010. Given the dearth of information on this topic, I also conducted about a dozen semi-structured inter- mentions that the internationalization of higher education in China has broadened students' awareness of international issues and taught them about foreign governments, economics, and culture (Zhang 2006). The article suggests that Chinese universities need to teach students to become world citizens to allow them to participate in world affairs. Another scholar argues that because of internationalization, IR courses should become a compulsory part of curricula at Chinese universities (Fu 2001).

This literature and articles in the English language China Daily confirm that the 1978 reforms have had an obvious impact on Chinese universities, their openness to ideas from abroad, and the ability of students to learn more about the world, if only informally. The large numbers of Chinese people going abroad and foreigners coming to China continue to provide students with significant international exposure. Chinese students have been studying abroad since the 1980 s, but the number is rising rapidly. Between 1978 and 2006, more than one million Chinese studied abroad; in 2008 alone, almost 180,000 students left to study overseas (Ying 2008). Most of these students go to the United States or the United Kingdom, and 90\% are self-financed (People's Daily 2009). Since returning students infuse campuses with valued expertise, foreign Ph.D.s, and international perspective, the government has taken steps to ensure that more Chinese students return home after traveling out of the country. In 2006 , only $26 \%$ of overseas Chinese students returned home; in the same year, the statefunded Study Abroad Program enlarged its scope and stipulated that students who received fellowships must return home upon graduation (Ministry of Education of the People's Republic of China 2007, 345-59). 
Meanwhile, the government has been investing in its own universities, improving standards and internationalizing campuses in the hope that China will become a destination for higher education. In 1950, China received its first group of foreign students when 33 students arrived from Eastern Europe; since then, over 1.2 million foreigners have studied in China. In 2007, 195,00o foreign students were studying in China and 68,ooo were seeking a diploma (20\% more than the previous year; China Daily 2008). Foreign students come from some 188 countries or regions, but almost three-quarters come from other areas of Asia to study language, medicine, science, or engineering (China Daily 2008). In 2007, the government increased scholarships for foreign students by $40 \%$ over the previous year (Ying and Lie 2008). Faculty and administrator exchanges are also rising, and in 2006, the Ministry of Higher Education hired over 21,00o foreign teachers at a cost of over $\$ 56$ million (Ministry of Education of the People's Republic of China 2007, 351).

One might assume that China's embrace of the West and the internationalization of its universities with regard to student and faculty exchanges had also affected the formal study of international issues or the field of IR, but this assumption is not necessarily true. When I arrived in 2008 to teach at XJTU for the first time, I was surprised to find that the university did not have any IR classes, and I was told that there were not even classes in foreign policy, international organizations, or world history. XJTU is one of China's best engineering schools, ranked eighth in the country for science and technological innovation; in 1994, it established the College of Humanities and Social Science (Research Center for China Science Evaluation 2008). Although my students were all required to take classes from the political science department, they assured me that they had no background for my class. ${ }^{4}$ My return to XJTU in 2009 and subsequent experiences teaching another IR class provided further evidence of the discipline's nascent development, as well as the university's openness to this field.

\section{IR STUDIES IN CHINA}

Starting in the 1930s, the Soviet Union exerted a profound influence on Chinese higher education, particularly regarding the development of technical universities and specialized teacher training colleges. In the field of IR, research and teaching were distorted and limited by Marxist-Leninist doctrine that required teachers to emphasize the causes and effects of the international communist struggle. In 1952, with the country in the throes of political change, the government abolished political science departments throughout the country (Baoxu 1984). Political science as a discipline was not officially revived until 1978, and in 1981, the government approved a five-year plan for research in six major areas, including "international relations and the problems of world politics" (Baoxu 1984, 752). By this point, IR had emerged as a separate discipline in China because of the Sino-Soviet split in the 1960s that pushed for the creation of IR institutes to develop a Chinese (rather than Soviet) perspective on the communist struggle and the world (Shambaugh 1992). Beginning in 1963, the government established international politics departments at Peking University, 5 Renmin University, and Fudan University, making these institutions the only universities at the time that focused on IR in any way. ${ }^{6}$ In fact, the first political scientists in the PRC received their training from the departments of international politics at Peking and Fudan universities (Baoxu 1984, 753-54). When
Peking University was authorized to create a political science unit, the faculty was drawn from its international politics department (Petracca 1990). Yet, wherever IR was taught, Marxism was infused into teaching and research, which was normative and prescriptive (Shambaugh and Jisi 1984, 758-64).

The 1978 reforms have had a direct and positive impact on social science, although the path has not always been smooth. In the wake of the 1989 Tiananmen Square protests, for example, all social sciences were put under close scrutiny, professors were targeted for "special treatment," and students were banned from studying these fields. Political science was considered one of the "suspended specialties" in which the state would no longer qualify personnel to teach (Petracca 1990, 256-57). Interestingly, the 1990 s turned out to be period of growth for IR study, which experienced its first stage of "opening and importing" from 1978 to 1989, followed by a stage of "absorbing and originating" from 1990 to 2001 (Yi et al. 1999). The development of IR was directly related to the government's push to normalize relations with its neighbors, increasing the need for more policy-relevant research on international issues. This motivation is reflected in the research conducted by Chinese scholars during this period. Content analysis of Chinese IR journals from 1995 to 1998 found that about $82 \%$ of the articles focused on "current affairs analyses," while only $18 \%$ contained theoretical analysis (Johnston 2003, 12). Another survey of journals published between 1996 and 2001 indicated that almost half of all articles (49\%) were devoted to area studies, although scholars also focused on international political economy, international institutions, and cooperation (Jisi 2002, 9). By 2001, scholars had started to reassess the field with a more critical eye, focusing on a range of previously unexplored topics like ethnic relations and religion, human rights, and theory development (Jisi 2002, 7-9).

Chinese IR has been increasingly influenced by Western theories and thinking. One study that examined five Chinese IR publications found that from 1978 to 1990, only two Western IR publications had been translated into Chinese. From 1991 to 2000, 10 translations were done, and from 2001 to 2007 , there were 74 (Yaqing 2007). Other studies note that Chinese IR syllabi are often dominated by Western (particularly American) IR theorists, and that students are increasingly required to read texts in English (Shambaugh and Jisi 1984; Zhang 2002; Jisi 2002). On paper and in person, Chinese scholars note that they are not content to follow and translate Western debates but are eager to provide a Chinese perspective on the field. Starting in the early 1990s, IR scholars debated the need for Chinese IR theory; lately, these debates have waned, but scholars still assert that a Chinese perspective is both necessary and inevitable (Yaqing 2007). IR theories, from the concept of democratic peace to the notion of the clash of civilizations, originated from a Western context and were shaped by a history that China does not share (Zhang 2002,104). After more than a decade, little progress in developing a uniquely Chinese IR is evident, and Chinese scholars still spend much of their research time translating works from English (Zhang 2002, 103). Although Chinese students are exposed to more Western theories and research, IR classes are almost devoid of methodology, and other than a few short workshops or an isolated methods class, they are taught neither qualitative nor quantitative skills. This gap is reflected in Chinese scholarship, which is less ideological now than in previous decades but continues to adopt a "holistic" approach that relies on extensive 
literature review and lists all possible reasons for an event instead of isolating variables to explain outcomes.

\section{TEACHING IR IN CHINA}

There is a growing IR literature in Chinese, although most is policy-oriented or focuses on the state of IR research (Shi 2008; Yu and Chen 1999). In English, scholars have done a good job documenting the early development of IR studies in China and explaining trends in research (Shambaugh and Jisi 1984; Shambaugh 1992; Shambaugh 2002). Yet, neither in Chinese nor in English have scholars provided an account of how the teaching of IR has changed in the last thirty years or how the profession has developed. Although the discipline has its own identity that is separate from political science, the field remains underdeveloped (Zhang 2002). China has over 1,860 universities and colleges, but the education system remains highly centralized and dominated by government planning and budgetary priorities (Yang, Vidovich, and Currie 2007). IR as a discipline remains concentrated in a small number of government-sponsored institutions and is taught largely at China's top social science universities. Nonetheless, changes have been evident in the years since the early 1980 s, when only three universities had IR departments and each was required to specialize in a particular area (Peking on the developing world, Renmin on the socialist world, and Fudan on the developed world). In 2006, the China National Association for International Studies (CNAIS), the national association for this field, listed 68 organizational members, including 36 IR departments in Chinese universities (Yaqing 2007). There are about a dozen Chinese IR journals and magazines, but most are either published by the Communist Party or are interested in descriptive, historical research.7 One Web site devoted to the subject of IR studies in China (http:// www.irchina.org/en/index.asp) offers a list of 44 academic institutes and universities devoted to IR research or teaching.

It is impossible to discern the quality of these IR programs, as no formal rankings for political science or IR exist. However, based on three different rankings of China's best social science universities and interviews conducted in China, Peking University, Tsinghua University, Renmin University, Fudan University, Nanjing University, and Nankai University are generally considered the best places to study IR in the country (see table 1). ${ }^{8}$ The existence of IR programs depends on a university's interests, but the Ministry of Education authorizes new departments and, more important, provides funding for research. The strength of these programs and the quality of the classes ultimately depend on faculty, the university's ties to foreign universities, and funding for research and innovative teaching. As Tianbiao Zhu of Peking University explains, changes in IR programs are certainly due to the government's policies of opening up that were inaugurated in 1978 , but the universities that are rising to the top in the discipline are the result of administrators' priorities and faculty research and reputation: "What is happening in IR is an unplanned, messy process that is continually evolving" (interview with Tianbiao Zhu, June 4, 2008, Beijing, China). Tsinghua University is a model example of an institution that has chosen to become a leader in IR studies. Although Tsinghua University is one of China's top engineering schools, it has not historically emphasized social sciences. However, the institution recently declared its commitment to become a leader in both social science research and IR. As its Web site and IR faculty both maintain, the university wants to become "the MIT of China." 9 The university's IR program is devoted to the scientific, empirical study of IR and is the home of China's largest social science database and the Chinese Journal of International Politics, a peer-reviewed journal published by Oxford University Press and partially funded by the U.S.-based MacArthur Foundation (interview with Xuefeng, June 3 , 2008, Beijing, China). There is also some evidence that IR programs are growing in popularity at both the undergraduate and graduate levels and among both Chinese and foreign students. In 2009, Peking University started an English language MA degree in IR (for international students), and Tsinghua University is planning a similar program. Although Chinese students do not often begin their studies by majoring in IR, they switch majors once they find topics that are interesting and, most important, marketable in China's new economy ${ }^{10}$

As a foreigner teaching IR in China, I found the country's academic culture to be at odds with the country's embrace of the West and change. In fact, I found the culture to be a throwback to an earlier period, an isolating intellectual and social experience in which openness and change were ideals rather than practices. This feeling was only partly related to XJTU's engineering focus and the dearth of social scientists. After several hours talking with a Chinese colleague at another university, I admitted that I had missed these kinds of discussions. He confessed that he too longed for stimulating conversations on research and teaching, but explained that this kind of dialogue is still not part of the academic culture in China. The IR faculty I met were a mixture of younger, well-trained scholars (many of whom had received their Ph.D.s outside of China) and older faculty trained in China who had successfully negotiated the world of guanxi (connections). What was apparent and refreshing was that younger scholars seemed to be committed to expanding empirical social science research and improving standards in research and teaching. However, Chinese and foreigners alike maintain that academia remains the last bastion of socialism; government support and connections, rather than scholarship or good teaching, remain the most important elements of professional success. Professors teach their classes and do not linger on campus; they often do not have offices, or they are burdened by excessive teaching responsibilities (in Xi'an, professors had classes every day), numerous meetings that are often unscheduled and obligatory, or paid consultancies that are often necessary to supplement their modest academic salaries (Hickey 2008). As one Chinese student put it, professors seem interested neither in teaching nor in research, but they are "bewitched" by promotion. Faculty seminars and brown bag lunches are unheard of, as is a faculty member attending a colleague's talk. In Xi'an, moreover, there is still some stigma associated with studying politics, and I was encouraged to tell people that I taught international public policy, with an emphasis on policy (see Petracca 1990).

At the same time, teaching IR in China is a more open endeavor than one might assume. No one will monitor your class, and universities are not particularly interested in the content of your syllabus. In Xi' an, I was easily able to send students articles that I assigned, and the content of my class was not monitored in any obvious or direct way. In class, I could and did talk about many issues such as human rights, democracy, and ethnic conflict that one might assume the government or university would deem sensitive. Students seemed neither surprised nor concerned, and they enjoyed discussing these issues. Western colleagues who have been living in China for years assured me that almost anything goes, especially at China's top universities, and 
Table 1

Top IR Programs in China

\begin{tabular}{|c|c|c|c|c|c|c|}
\hline & PEKING & TSINGHUA & RENMIN & FUDAN & NANJING & NANKAI \\
\hline Number of IR programs & 6 & $2(1)$ & 4 & 2 & $6(3)$ & 1 \\
\hline $\begin{array}{l}\text { Names of schools, colleges, } \\
\text { or centers }\end{array}$ & $\begin{array}{l}\text { School of International } \\
\text { Service (SIS) }\end{array}$ & 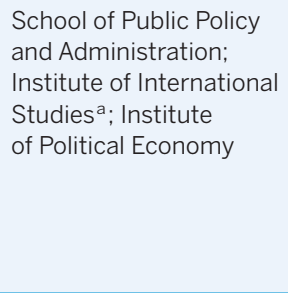 & $\begin{array}{l}\text { School of International } \\
\text { Studies; Center of } \\
\text { Globalization Studies } \\
\text { in the International } \\
\text { College }^{b}\end{array}$ & $\begin{array}{l}\text { School of International } \\
\text { Relations and Public } \\
\text { Affairs; Center for } \\
\text { American Studies }\end{array}$ & $\begin{array}{l}\text { International Relations } \\
\text { School }{ }^{\mathrm{b}} \text { S School of } \\
\text { International Business; } \\
\text { John Hopkins-Nanjing } \\
\text { Center for Chinese and } \\
\text { American Studies; } \\
\text { Department of Political } \\
\text { Science; European } \\
\text { Studies Center }\end{array}$ & $\begin{array}{l}\text { Zhou Enlai School } \\
\text { of Government }\end{array}$ \\
\hline Faculty members $(n)$ & 58 & 66 & 84 & 72 & 131 & 13 \\
\hline $\begin{array}{l}\text { Faculty members with foreign } \\
\text { Ph.D.s }(n)\end{array}$ & 10 & 21 & 4 & 9 & 6 & 1 \\
\hline Other international programs & $\begin{array}{l}\text { International economy } \\
\text { and trade BA on } \\
\text { international cultural } \\
\text { exchange; BIMBA } \\
\text { (Beijing International } \\
\text { MBA) from the China } \\
\text { Center for Economic } \\
\text { Research (CCER) }\end{array}$ & $\begin{array}{l}\text { International trade and } \\
\text { finance }\end{array}$ & $\begin{array}{l}\text { International economy } \\
\text { and trade/international } \\
\text { business }\end{array}$ & $\begin{array}{l}\text { International economy } \\
\text { and trade }\end{array}$ & $\begin{array}{l}\text { International trade } \\
\text { and business }\end{array}$ & None \\
\hline Program focus (year established) & $\begin{array}{l}\text { International politics (1963); } \\
\text { diplomacy (1966); } \\
\text { international political } \\
\text { economy (2002) }\end{array}$ & $\begin{array}{l}\text { International relations }{ }^{c} \\
\text { (2007); international } \\
\text { politics (1997) }\end{array}$ & $\begin{array}{l}\text { International politics } \\
\text { (1964)/diplomacy } \\
\text { (1950) }\end{array}$ & $\begin{array}{l}\text { International politics } \\
\text { (1964) }\end{array}$ & $\begin{array}{l}\text { International politics } \\
(2002)\end{array}$ & $\begin{array}{l}\text { International relations } \\
\text { (2003) }\end{array}$ \\
\hline Focus of research & $\begin{array}{l}\text { IPE, security studies, } \\
\text { Chinese foreign policy, } \\
\text { Taiwan }\end{array}$ & $\begin{array}{l}\text { Policy-focused research } \\
\text { with emphasis on social } \\
\text { science methodology; } \\
\text { IIS-focused research } \\
\text { including politics, IR } \\
\text { theory, IPE, history } \\
\text { of IR, and area } \\
\text { studies }\end{array}$ & $\begin{array}{l}\text { IPE; religion in IR; U.S. } \\
\text { foreign policy and } \\
\text { security studies }\end{array}$ & $\begin{array}{l}\text { Security studies; technical } \\
\text { and scientific issues; } \\
\text { IR theory }\end{array}$ & $\begin{array}{l}\text { U.S.-Chinese relations; } \\
\text { history of IR; international } \\
\text { politics/law/organizations. }\end{array}$ & $\begin{array}{l}\text { Nontraditional security } \\
\text { issues; globalization } \\
\text { and IR theory }\end{array}$ \\
\hline $\begin{array}{l}\text { Number of undergraduates focused } \\
\text { on political studies }\end{array}$ & 554 (2007) & $52(2007)$ & $450(2007)$ & $\sim 400$ (2000) & $\mathrm{n} / \mathrm{a}$ & $\mathrm{n} / \mathrm{a}$ \\
\hline
\end{tabular}

aThe Chinese Web site shows that this institute has seven subcenters: National Security, Japanese Studies, European Studies, U.S.-China Relations, Chinese Foreign Policy, Arms Control, and Economy and Diplomacy.

According to a Chinese discussion forum ("Sina," http://edu.sina.com.cn/gaokao/08dxjz//index.html), this school originated from a research unit of the history department. Although this unit has been transformed into the "International Relations School" since 2000, it still does not have substantial or physical departments, and most faculty come from the history department.

"This program belongs to the Institute of International Politics. On Tsinghua's Web site, English and Chinese versions, a "political science department" is still listed in the disciplinary categories. However, the link on the English version is not available, and the Chinese link transfers to the "international relations department." On the Chinese Web site of the international relations department, the department is listed as having five "classrooms of teaching and research." These are politics, including political theory and comparative politics; IR theory, including theory and methodology of IR studies; IPE, including theory of IPE and economy and diplomacy; history of IR, including international and Chinese diplomatic history; and area Studies. 
that IR is not a controversial field (see Bell 2006). Teaching comparative politics is a more sensitive job, because the material and discussion must necessarily compare what happens in foreign countries to what happens in China. During all of my visits, people reminded me that statements criticizing the government or the Party might provoke an intense, defensive discussion among students, if not a phone call from a university administrator. The most challenging part of teaching IR in China is being aware of what is acceptable in the classroom, which depends on one's location and ongoing political events, especially since the boundaries are not stated.

Finally, I would be remiss if I failed to mention that Chinese culture, with its strong patriarchal tradition, has noticeably affected who teaches at Chinese universities. At XJTU, I rarely encountered a female professor, and while this gender gap may be similar to the gap in top engineering colleges in the United States, one source indicated that female professors with Ph.D.s in China comprise only $2 \%$ of the faculty at nationally accredited universities. $^{11}$

\section{THE FUTURE OF IR STUDIES}

Predicting the future of IR as a discipline in China is difficult. Although change is one of the few constants in this nation, China is also a country where a single political event can delay a field's development overnight, as the Tiananmen Square protests in 1989 demonstrated. Nonetheless, there are reasons to believe that IR and other social sciences will increasingly play an important role in the country's future, helping it become a regional, if not global, leader (Lieberthal 1986). Chinese universities are changing at a breakneck pace, as the confusing assortment of colleges, departments, and centers at Chinese universities attest. Qingsi $\mathrm{Li}$ of Renmin University maintained that the oldest IR programs are still the country's strongest, but the field is in flux because of the nation's enormous need for students with linguistic expertise and knowledge of the world (interview with Li, June 2, 2008, Beijing, China). The need for foreign language speakers has generated a number of interdisciplinary international studies programs, although their focus is unquestionably on foreign language instruction and teaching. The department of international studies at XJTU, for example, was formerly the department of foreign languages. Officially, this department teaches foreign languages, but depending on the instructor, classes might also be offered on American culture or European politics. My experience teaching in XJTU's School of Public Policy and Administration also demonstrates how IR classes are smuggled into classes from other departments. Thus, the lack of IR departments or programs does not necessarily mean that IR classes are not being taught, and in these ways, the teaching of IR will likely increase, although these trends will be even more difficult to measure. The future of IR may depend on the field's ability to maintain its distance from political science-given the latter's association with Marxism-and to affiliate itself with programs that discount politics. Area studies institutes, for example, have been crucial to the popularization of IR in China. Interest in the United States in particular has led to the development of well-regarded American studies programs that indirectly encourage IR teaching and research. For example, as a result of its successful American studies program, the Johns Hopkins-Nanjing University Center in Nanjing has become one of the country's most well-known IR programs. Established in 1986, the Center provides graduate train- ing for Chinese and international students, helping to make Nanjing one of the best places to study IR in China.

Some China experts are quite optimistic about the impact of Chinese reforms on the internationalization of Chinese universities and their influence on how political science is taught in China (interview with Daniel Bell, June 1, 2008, Beijing, China). Ongoing political debates, especially those that engage Confucian values to respond to the country's economic goals and political quandaries are particularly interesting, but how these debates and the importance of harmony, justice, and self-criticism might inform IR as a discipline is yet to be seen (Bell 2008; interview with Daniel Bell, June 1, 2008, Beijing, China). It is clear that China intends to expand and intensify its relations with other countries, and success in these areas requires a sound understanding of IR, as well as analysis that is as objective as possible.

Currently, China's leadership is dominated by engineers and people who see the world in terms of established laws, regularities, and controls that can be manipulated like levers on a machine (Lampson 2007). IR cannot boast these traits. However, as the Chinese government recognizes that openness and internationalization can work to its broad benefit, the discipline will flourish to ensure that its citizens will be able to take advantage of new career opportunities, and that its leaders will be more in tune with the imprecise principles of IR. $=$

\section{NOTES}

I thank Tracy Zhao and Pei-Shiue Hsieh for their research assistance on this article.

1. Although the term internationalization is contested, I define it as "a multifaceted process of integrating an international and intercultural dimension into the curriculum, research and service functions" (Knight 2004, 11).

2. As in English, other words are used in Chinese to describe this field, including international studies, international affairs, and foreign affairs. For a recent discussion of this topic, see Jisi (2002); for an older discussion of these terms in Chinese, see Shambaugh and Jisi (1984).

3. Although my experiences are largely drawn from Xi'an, I travelled throughout China in 2007, 2008, and 2009, inquiring about the status of IR programs at Chinese universities. In 2008, I interviewed professors from Tsinghua, Renmin, Peking, and the China Foreign Affairs universities about the history and development of IR programs in China. Conversations and correspondence with the following also informed this research: Zhenping Feng, director, XJTU department of international cooperation; Liang Li, XJTU vice director, department of international cooperation; Dr. Andrew Wedeman, visiting professor, Nanjing University; Dennis V. Hickey, Fulbright exchange professor (2009), China Foreign Affairs University; Daniel Bell, Tsinghua University; Matt Ferchen, Tsinghua University; Shawn Shieh, visiting faculty, CET Chinese studies program; Zingsi Li, Renmin University; Mei Renyi, Beijing Foreign Studies University; Xuefeng, Tsinghua University; Tianbiao Zhu, Peking University.

4. Since 2005, both the Propaganda Department of the Communist Party and the Ministry of Education have requested that universities teach one twocredit course, along with four other required courses, in political science. These four required courses are taught by professors of Marxist theory and ideological and political education, not political science or IR.

5. Founded in 1898 as the Imperial University of Peking, this institution has been called Peking University since 1912, even though in English, the pinyin transliteration of the city of Peking is written as Beijing. Although the Chinese government adopted pinyin and a Latin alphabet in 1949, it did not enforce the use of the name Beijing until the 1980 .

6. This more likely merely reflects a change in terminology, because "political science" had become taboo.

7. For more information, see http://china.eastview.com/kns5o/ Navigator.aspx?ID=CJFD.

8. To formulate this list, I relied on the Comprehensive Competitiveness Ranking of Chinese Key Universities-Public Universities from the Institute of Higher Education at Shanghai Jiaotong University's Research Center for China Science Evaluation (http://rccse.whu.edu.cn/default.asp); the 2007 Times Higher Education Supplement ranking of top universities in mainland China; and "The Best Universities in Mainland China" from the Wuhan Centre for China Science Evaluation 2006. 
9. This idea was mentioned by several faculty members such as Xuefeng and Matt Ferchen in my discussions about IR programs at Tsinghua on June 3 , 2008.

10. I thank Matt Ferchen for this point.

11. In China, you do not need a Ph.D. to teach at the university level, and instructors are still referred to as "professors" even if they only have an MA or BA degree. See Wang (2008).

\section{REFEREN C ES}

Baoxu, Zhao. 1984. “The Revival of Political Science in China.” PS: Political Science and Politics 17 (4): 745-57.

Bell, Daniel A. 2006. "Teaching Political Theory in Beijing." Dissent Spring: 9-17.

. 2008. From Communism to Confucianism. Princeton, NJ: Princeton University Press.

China Daily. 2008. "Bid to Attract Foreign Students Gears Up." China Daily, April 24. http://english.peopledaily.com.cn/90001/6398067.html.

Du, Jiancun, and Hengbin Wu. 1994. "Guanyu Jiaoshou Shijie Zhengzhi Jingji Yu Guoji Guanxi Jiaocai de Yijian.” Gaoxiao Lilun Cankao 43 (9): 42-45.

$\mathrm{Fu}$, Zhitian. 2001. “Thought of Internationalization of China's Higher Education.” Shanghai Education 9: 12-15

Hickey, Dennis V. 2008. "Returning to Teach in China." Chronicle of Higher Education, November 5. http://chronicle.com/article/Returning-to-Teach-in-China/ 45830 .

Jisi, Wang. 2002. "International Relations Studies in China Today: Achievements, Trends and Conditions." Report to the Ford Foundation. http:// www.irchina.org/en/pdf/IRSC_wang_jisi_english.pdf.

Johnston, Alastair Iain. 2003. "The State of International Relations Research in China: Considerations for the Ford Foundation." Unpublished Report.

Junling, Yin. 2003. "Considerations on Curricular Reform for 'Contemporary World Political Economy and International Relations.'” Journal of Taiyuan Teachers College 2 (2): 102-03.

Knight, Jane. 2004. "Internationalization of Higher Education Practices and Priorities: 2003 IAU Survey Report." International Association of Universities. http://www.iau-aiu.net/internationalization/pdf/Internationalisation-en.pdf.

Lampson, David M. 2007. “The Faces of Chinese Power.” Foreign Affairs 86 (1): $115-27$.

Li, C. M. 2007. "Economic Globalization and the Internationalization of Chinese Higher Education." Group Economy October: 40-41.

Li, Yujun. 2003. "Gaoxiao Zhengzhi Lilun Ke Kechixu Fazhan Shi Jiaoxue Tanxi: Jiantan Shijie Jingji Zhengzhi Yu Guoji Guanxi de Jiaoxue Tihui." Journal of Liuzhou Teachers College 18 (1): 74-76.

Lieberthal, Kenneth. 1986. "China and Political Science." PS: Political Science and Politics 19 (1): 48-54.

Ministry of Education of the People's Republic of China. 2007. China Education Yearbook. Beijing: People's Education Press.
People's Daily. 2009. "Chinese Students Studying Abroad Exceed 1.39 Million." People's Daily Online, March 26. http://english.peopledaily.com.cn/90001/90776/ 90882/6622888.html.

Petracca, Marc. 1990. "Political Science in China: A New State of Siege." PS: Political Science \& Politics 23 (2): 253-57.

Research Center for China Science Evaluation. 2008. "Sina." http:// edu.sina.com.cn/gaokao/o8dxjzl/index.html.

Shambaugh, David L. 1992. "The Soviet Influence on China's Worldview." Austra lian Journal of Chinese Affairs 27: 151-58.

. 2002. "China's International Relations Think Tanks: Evolving Structure and Process." China Quarterly 171: 575-96.

Shambaugh, David L., and Wang Jisi. 1984. "Research on International Studies in the PRC.” PS: Political Science \& Politics 17 (4): 758-64.

Shi, Yinhong. 2008. "Sanshinian Lai Zhongguo Guoji Zhengzhi Yanjiu de Ruogan Wenti." Contemporary World \& Socialism 4: 72-75.

$\mathrm{Su}, \mathrm{Z}$., and J. M. Liang. 2007. "International Exchange and Cooperation of Higher Education Institutes." China Adult Education December: 28-29.

Wang, Fang. 2008. "Zhongguo Gaoxiao Nvjiaoshi Duiwu de Lishi Bianqian jiqi Shehui Diwei de Bianhua." Jiaoshi Jiaoyu Yanjiu 2: 69.

Wang, Y. B. 1999. "Internationalization of Higher Education: Background, Trend and Choice of Strategy." Exploring Education Development February: 1-5.

Xu, J. N., and Y. P. Xie. 2003. "Internationalization of Chinese Higher Education." Journal of South-Central University for Nationalities 23: 309-10.

Yang, Rui. 2005. "Internationalizing Chinese Higher Education: A Case Study of a Major Comprehensive University." In Internationalizing Higher Education: Criti cal Explorations of Pedagogy and Policy, ed. Peter Ninnes and Meeri Hellstén, 97-118. Dordrecht, The Netherlands: Springer.

Yang, Rui, Lesley Vidovich, and Jan Currie. 2007. “'Dancing in a Cage': Changing Autonomy in Chinese Higher Education.” Higher Education 54 (4): 575-92.

Yaqing, Qin. 2007. "Why is There No Chinese International Relations Theory?" International Relations of the Asia-Pacific 7 (3): 313-40.

Yi, Lu, Gu Guanfu, Yu Zhengliang, and Fu Yaozu, eds. 1999. Xin Shiqi Zhongguo Guoji Guanxi Lilun Yanjiu [Research on International Relations Theories in China's New Era]. Beijing: Shishi Chubanshe.

Ying, Wang. 2008. "Record Number of Students to Travel Abroad." China Daily, January 17 .

Ying, Wang, and Ma Lie. 2008. "Bid to Attract Foreign Students Gears Up." China Daily, April 24.

Yu, Zhengliang, and Yugang Chen. 1999. "Zhongguo Guoji Guanxi de Zhanlue Zhuanxing yu Lilun Yanjiu Ershinian." Fudan Journal (Social Science) 1: 12-17.

Zhang, S. Q. 2006. "Several Strategies of Internationalization of Chinese Higher Education." Jiangsu Higher Education February: 54-55.

Zhang, Yongjin. 2002. "International Relations Theory in China Today: The State of the Field." China Journal 47: 101-08.

\section{APPENDIX}

\section{Chinese IR Journals in English:}

China International Studies (http://www.ciis.org.cn/en/publications1.asp)

China \& World Economy (http://www.wiley.com/bw/journal.asp?ref=1671-2234)

The Chinese Journal of International Politics (http://cjip.oxfordjournals.org/)

Chinese IR Web Sites in English:

http://www.irchina.org/en/index.asp (Nankai University) 


\title{
CAMBRIDGE
}

\section{JOURNALS}

Politics \&o Gender

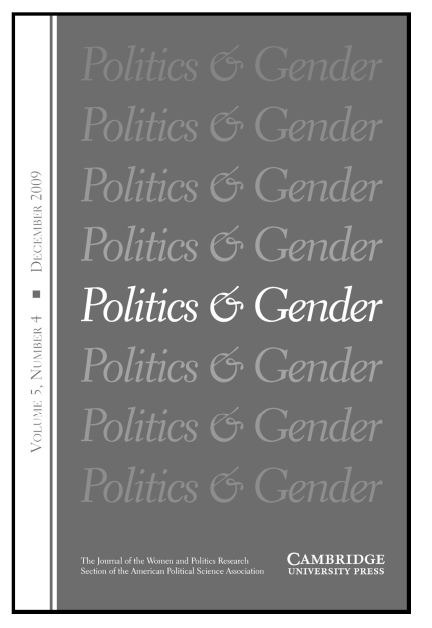

Published for the

Women and Politics Research Section of APSA

\section{Editor:}

Jennifer L. Lawless

American University, USA

Politics \& Gender is an agenda-setting journal that publishes the highest quality scholarship on gender and politics and on women and politics. It aims to represent the full range of questions, issues, and approaches on gender and women across the major subfields of political science, including comparative politics, international relations, political theory, and U.S. politics. The Editors welcome studies that address fundamental questions in politics and political science from the perspective of gender, as well as those that interrogate and challenge standard theoretical approaches, methodologies, and analytical categories.

Quarterly. Volume 6, 2010. ISSN 1743-923X. E-ISSN 1743-9248

$\square$ Individuals, Print Only: \$98 / £55

$\square$ Institutions, Print + Online: \$273/£150

$\square$ Institutions, Online Only: \$239 / £131

Name

Email_

Address

$\square$ Check to Cambridge University Press in US \$ or $£$ Sterling

$\square$ Visa $\square$ MasterCard $\square$ American Express

Card number

Signature
Expiry

\section{Subscribe!}

Recommend Politics \& Gender to your librarian directly from its homepage -

FREE online access for you when your library subscribes!

In the U.S., Canada, or Mexico, in US \$:

Journals Marketing Dept

Cambridge University Press

32 Avenue of the Americas

New York, NY 10013-2473, USA

Tel: $800-872-7423$ or $845-353-7500$

Fax: 845-353-4141

journals_subscriptions@cambridge.org

Elsewhere in the world, in $£$ Sterling:

Cambridge University Press Journals Customer Services Dept Edinburgh Building Shaftesbury Road Cambridge CB2 8RU UK Tel: +44 (0) 1223326070

Fax: +44 (0) 1223325150 journals@cambridge.org
\end{abstract}

\section{journals.cambridge.org/pag}

